\title{
Sustainable Circular Bioeconomy-Feasibility of Recycled Nutrients for Biomass Production within a Pulp and Paper Integration in Indonesia, Southeast Asia
}

\author{
Mirja Mikkilä *D, Papitchaya Utanun, Jukka Luhas, Mika Horttanainen and Lassi Linnanen \\ Department of Sustainability Science, Lappeenranta-Lahti University of Technology, P.O. Box 20, \\ 53851 Lappeenranta, Finland; papitchaya.u@gmail.com (P.U.); jukka.luhas@lut.fi (J.L.); \\ mika.horttanainen@lut.fi (M.H.); lassi.linnanen@lut.fi (L.L.) \\ * Correspondence: mirja.mikkila@lut.fi
}

\section{check for} updates

Citation: Mikkilä, M.; Utanun, P.; Luhas, J.; Horttanainen, M.; Linnanen, L. Sustainable Circular BioeconomyFeasibility of Recycled Nutrients for Biomass Production within a Pulp and Paper Integration in Indonesia, Southeast Asia. Sustainability 2021, 13, 10169. https://doi.org/10.3390/ su131810169

Academic Editors: Adriana Del Borghi and Joshua M. Pearce

Received: 1 June 2021

Accepted: 8 September 2021

Published: 10 September 2021

Publisher's Note: MDPI stays neutral with regard to jurisdictional claims in published maps and institutional affiliations.

Copyright: (c) 2021 by the authors. Licensee MDPI, Basel, Switzerland. This article is an open access article distributed under the terms and conditions of the Creative Commons Attribution (CC BY) license (https:// creativecommons.org/licenses/by/ $4.0 /)$.
Abstract: Sustainable biomass production based on efficient carbon and nutrient recycling is crucial in materially efficient, sustainable biobased production. A circular bioeconomy model of the replacement of mineral fertilizers with recycled nutrients from pulp and paper mill sludge is tested here within a hypothetical case from Indonesia, Southeast Asia. First, the financial feasibility of the use of recycled nutrients originating from pulp and paper processes was analyzed in fast-growing pulpwood production. Secondly, the comprehensive social and environmental benefits of the practice were analyzed through qualitative sustainability analysis. The availability of the basic material of all required parameters referring to Indonesia limited the analysis period to be from 1996 to 2013. The establishment costs of a pulpwood plantation were adjusted according to a reference study, while the other data were compiled from various sources. The financial profitability of the circular model was analysed by using two indicators, net present value (NPV) and internal rate on return (IRR). The application of sludge-based recycled nutrients slightly increased the establishment costs in some circumstances but had no direct impact on the financial profitability, as the financial profitability was not sensitive to the establishment costs. The results showed that the financial profitability of biomass production is not sensitive to the plantation establishment and management costs. The profitability depends on the mean annual increment and product price. The qualitative analysis showed a holistic value of the practice that goes beyond the direct benefits. The use of sludge-based recycled nutrients in the production of pulpwood closed the economic loop, which is illustrative of the circular bioeconomy within the integrated pulp and paper sector including the raw material source, forest plantation.

Keywords: financial profitability; forest management; pulp and paper industry; pulpwood plantation; reforestation; recycled nutrients; sludge; sustainability

\section{Introduction}

The current economic system and related food and other biomass production is based on the linear, inefficient utilization of global resources. One of the main reasons for grand environmental challenges is the incomplete (commercial) valuation of natural resources in terms of the exploitation cost and the full value of products, which leads to the overexploitation of natural capital [1]. An alternative production model to the existing linear and open-ended bioeconomy systems, namely, a circular bioeconomy, should be based on business renewal and new types of structural and functional solutions through out various value-adding chains covering technological, institutional, and social changes [2].

The role of biobased products is ever increasing due to the exhaustion of non-renewable raw materials. Rockström et al. [3] have defined the safe operating space for human societies through critical planetary boundaries at the global level, and Steffen et al. [4] have completed the work by accounting for the regional-level heterogeneity. Biosphere integrity, 
i.e., biodiversity loss, and biogeochemical flows, i.e., phosphorus and nutrient cycling, have transgressed their sustainable level most seriously while Land-system change and Climate change, both relating intensively to the carbon cycle, are closing the resilience of the system.

The efficient supply of biomasses requires industrial-scale production systems leading to a variety of environmental problems, including nutrient-induced environmental change [5]. Rockström et al. [3] have estimated that large amounts of nitrogen and phosphorus caused by human processes lead to concern over the global cycles of these two substances, especially nitrogen, which has already exceeded its boundary. The need for nitrogen-based fertilizers in various types of biomass production is one of the major causes for disturbing global cycles, as the annual production converts more than a hundred million tons of $\mathrm{N}_{2}$ from the atmosphere into new reactive forms, having negative environmental consequences. This conversion is also a very energy intensive process with the use of fossil fuels [6] (Worrell et al., 2000), increasing greenhouse gases and further strengthening climate change. Around 9 million tons of phosphorus, the other key nutrient, ends up in the oceans, speeding up the nitrification of water ecosystems [4,7]. Especially, non-renewable nutrients become even scarcer due to the population growth and consequent increasing volume of fertilizers in food production [8]. Due to the negative environmental impacts and limited availability of non-renewable nutrients, it is relevant and justified to identify the financial and environmental potential of recycled nutrients as compensation of new mineral nutrients. Here, we assess the feasibility of recycled nutrients in industrial-scale biomass production, namely within a hypothetical integration of fast-growing pulpwood plantation and pulp and paper mill in Indonesia, Southeast Asia.

Sludge is one of organic residues which can be applied a soil amendment and a source of nutrients within agriculture and forestry $[9,10]$. Sludge from pulping and paper production and the related wastewater treatment also includes nutrients such as nitrogen and phosphorus. Pulp and paper mill (PPM) sludge is generally considered as waste to be disposed of by, for instance, landfilling [11]. However, this type of sludge can be processed into soil improvement material, including recycling nutrients. The sludge can be processed for soil conditioning, incineration, composting, and fertilizing. The PPM waste waters and sludges can be utilized safely as additional nutrient sources to mineral fertilizers and as soil improvement material amendments in agriculture and forest plantation production [12]. The advantages of this type of industrial sludge compared to community-based sludge are its homogeneity and predicable composition [13]. Although sewage sludge contains relatively higher degrees of nutrients [14], it may consist of harmful substances such as heavy metals and pathogens [15].

Furthermore, there is increasing pressure towards indigenous forests, and the consequent decrease in forest area requires actions to offset the negative impacts on ecosystem services at large. The over-logging of indigenous forests can change the ecosystem radically. For example, Imperata grasslands followed by over-logged rainforests in South Kalimantan, Indonesia, have no proper value for local communities, and the biodiversity is marginal compared to various forest ecosystems [16]. Deforestation not only has negative environmental impacts, but it can also lead to lower economic and social performance in the surrounding societies, for example, in terms of decreased water quality, lower value and production of various forest-based products, and diminishing working opportunities. Low-value grasslands can be reforested with fast-growing tree species. For example, Acacia mangium grows more rapidly than grass in the start-up competition and the wood quality fits well with the current pulp and paper process. After occupying the grassland, the same areas can be rehabilitated with indigenous tree species, leading to higher value and more diverse forests [17-19].

Commonly, the soil in the tropics can be relatively poor, and over-logged areas suffer from erosion and related nutrient leaking. Consequently, the establishment of plantations is based on intensive fertilization. In commercial wood production, one option is to replace a part of artificial fertilizers by recycling the nutrients of the industrial wood processing back 
to wood production. For example, the wastewater of modern PPM is treated with biological wastewater treatment technology that requires nutrients in the process. The purified but nutrient-rich water is led into the water ecosystems. Homogenous and relatively clean wastewater and sludge from pulp and paper processes are applicable additional nutrient sources to mineral fertilizers and soil improvement material in agricultural and forest plantation production. This would close the loop when considering the entire production chain from raw material source, pulpwood, to process, pulp, and paper, promoting the circular bioeconomy (Figure 1).

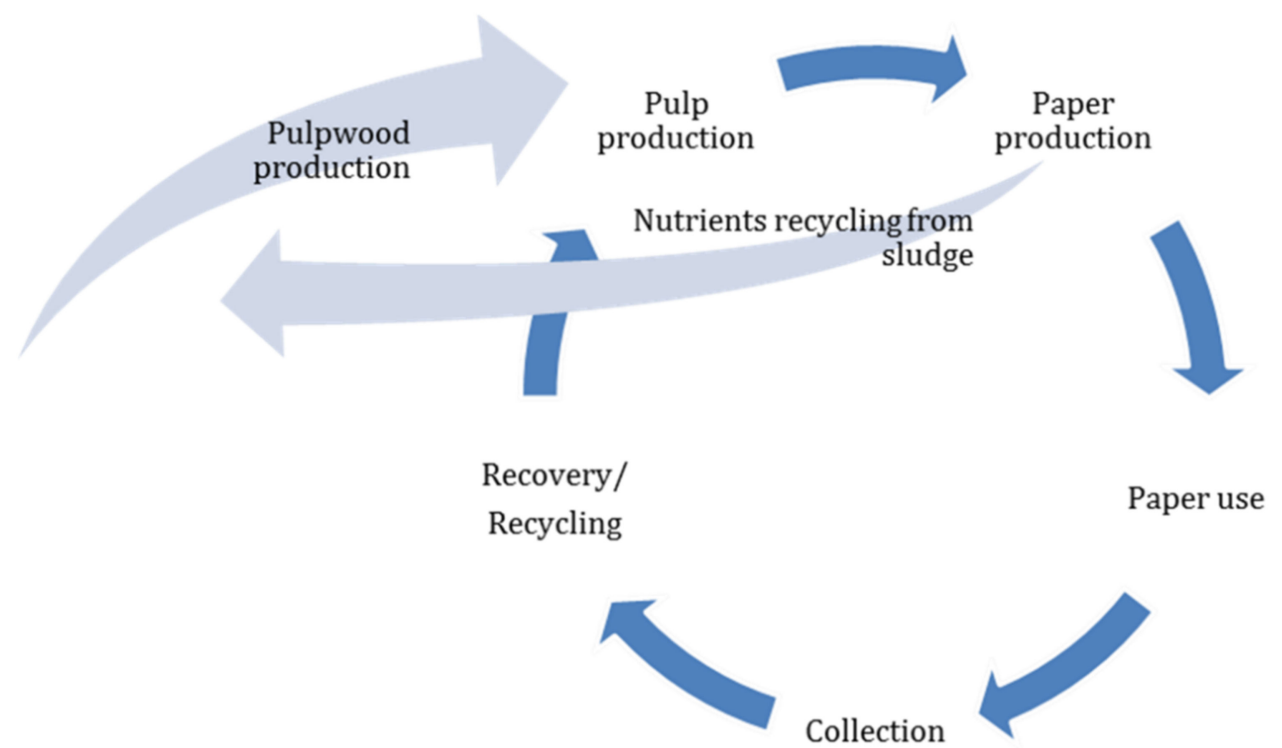

Figure 1. Circular bioeconomy model within pulp and paper production [20].

The increasing demand of both renewable and non-renewable raw material creates the need for new types of industrial-level, environmentally and financially feasible circular bioeconomy models. However, the development process is still on its way. This study completes the knowledge gap related the financially and environmentally feasible business models. The overall objective of the study is to build a comprehensive circular bioeconomy model for the raw material production of a hypothetical pulp and paper integrate located in Indonesia showing (1) the financial profitability of the use of PPM sludge based recycled nutrients as an input in the pulpwood production and (2) the social and environmental benefits of the practice. The study continues the analysis period by Kosonen et al. [16] covering the time span between 1996 and 2013. The availability of the basic material of all required parameters referring to Indonesia and the specific time span limited the analysis period.

The research design is based on the financial analysis by Kosonen et al. [16], completed with Utanun's [20] sludge application analysis. The paper introduces, first, the alternative to mineral fertilizers focusing on the use of recycled nutrients from pulp and paper mill sludge in the production of fast-growing pulpwood, including the variety of consequent benefits. Secondly, the material and methods are described. Then, the financial profitability and related strengths and challenges are discussed. Next, the potential social and environmental benefits of the practice are introduced. Finally, conclusions are drawn regarding the applicability of the circular bioeconomy approach on raw material production for the pulp and paper industry, and the need for further research is discussed. 


\section{Material and Methods}

\subsection{Research Design}

A circular bioeconomy model based on the further utilization of sludge form the pulp and paper production process was built based on the literature review (Figure 1). Traditionally, the sludge has been classified as waste ending in land filling or incineration. The value of sludge as a potential recycled nutrient and soil improvement material is tested through a financial analysis by replacing artificial fertilizer input with a sludge-based input. The sensitivity of financial profitability related to fertilizer input is tested in the sensitivity analysis. The second part of the analysis qualitatively investigates the potential social and environmental benefits on the application of sludge-based inputs in biomass production (Figure 2).

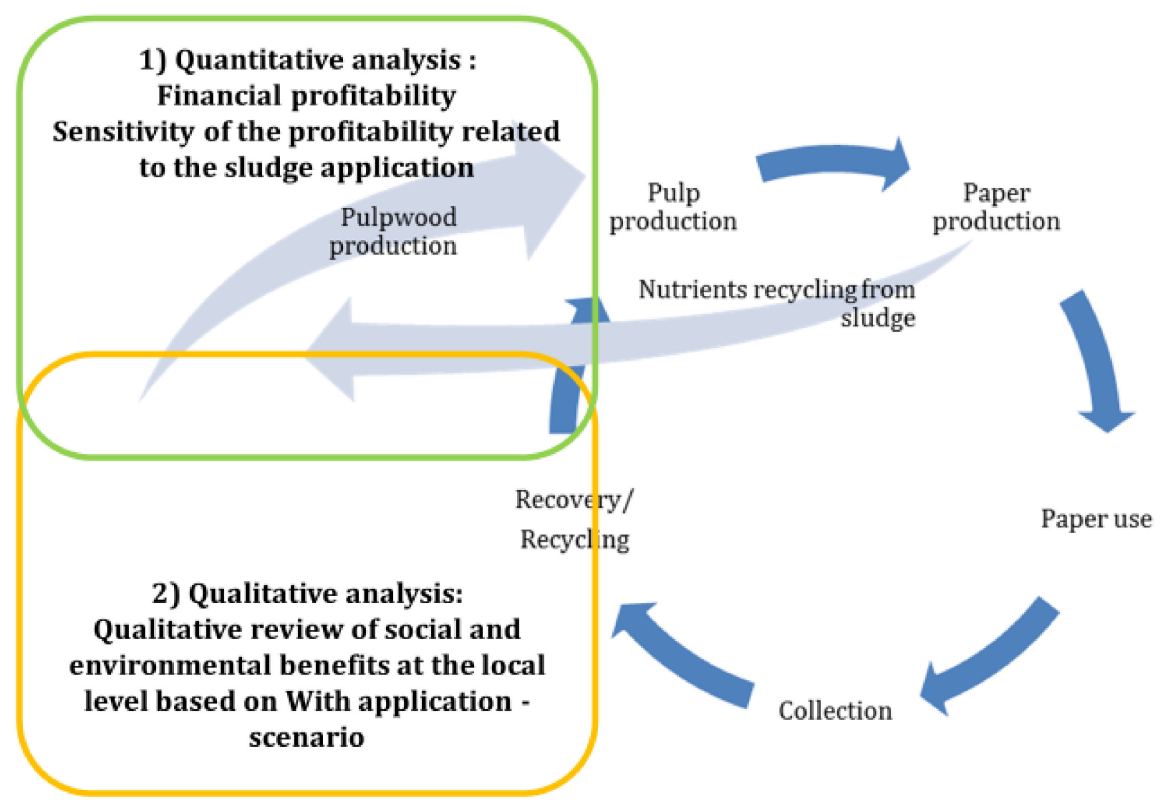

Figure 2. Research design and methodological focus.

\subsection{Materials}

\subsubsection{Characteristics of the Sludge}

The nutrient contents in the sludge were assessed on the sludge characteristics based on the research by Rashid et al. [21]. The data was selected based on a chemical analysis of paper mill biosolids in order to estimate an average nutrient concentration of the sludge regardless of the pulp and paper production and sludge treatment technologies (Table 1).

Table 1. Chemical analysis of primary and de-inking paper mill biosolids from different sources, adjusted according to [21].

\begin{tabular}{lccc}
\hline Analysis & $\begin{array}{c}\text { Goss et al., 2003 } \\
(\mathbf{n}=\mathbf{3})\end{array}$ & $\begin{array}{c}\text { Atiken et al., 1998 } \\
(\mathbf{n}=\mathbf{1})\end{array}$ & $\begin{array}{c}\text { Simard et al., 1998 } \\
(\mathbf{n}=\mathbf{3})\end{array}$ \\
\hline $\mathrm{EC}\left(\mathrm{mS} \mathrm{cm}^{-1}\right)$ & $0.39-0.87$ & & $0.09-0.20$ \\
$\mathrm{pH}$ & $7.7-8.2$ & 7.7 & $7.8-9.1$ \\
Dry matter (\% dry) & $39.7-49.0$ & 31.5 & \\
Organic Carbon (\% dry) & $29.7-33.4$ & 31.8 & $42.3-44.2$ \\
Total N (\% dry) & $0.27-0.73$ & 0.37 & 0.15 \\
C:N ratio & $42-124$ & 86 & $284-292$ \\
Total P $(\%)$ & $0.072-0.093$ & 0.08 & $0.0096-0.0097$ \\
Total K (\%) & $0-0.09$ & 0.20 & $0.0029-0.0034$ \\
Total Ca (\%) & $2.86-5.85$ & & $0.46-0.56$ \\
Total Mg $(\%)$ & $0-0.06$ & 0.235 & $0.026-0.031$ \\
Total Na (\%) & $0.05-0.06$ & & $0.073-0.084$ \\
\hline
\end{tabular}




\subsubsection{Pulpwood Production}

The production costs of fast-growing wood was based on the plantation of specific tree species such as Acacia mangium and Acacia crassicarpa. The production costs were adjusted according to Kosonen et al. [16] including establishment costs, variable costs, fixed costs, investments, and roundwood price (Table 2). The possible impact of the tree species on the outcome was excluded in this work. The productivity was based on the mean annual increment (MAI) of $25 \mathrm{~m}^{3} / \mathrm{ha}$, which is considered a relatively conservative estimate for a fast-growing plantation [16]. The planting area of $1000 \mathrm{ha}$, with an annual planted area of 100 ha, was applied in the analysis. Only the rotation time of 8 years and one rotation period were considered, resulting in the total plantation time of 18 years, the last plot of 100 ha was planted in the year 10 in the model.

Table 2. Basic production cost data used in the study, adjusted according to [16].

\begin{tabular}{|c|c|c|c|c|}
\hline Cost Item & & Remark & & Source \\
\hline Variable Cost & & & & Interviews, \\
\hline Establishment cost & USD/ha & & & 1994 \\
\hline Site preparation & 213 & 1st year & & \\
\hline Seedlings and their transport & 120 & 1st year & & \\
\hline Planting & 18 & 1st year & & \\
\hline Fertilization & 97 & 1st year & & \\
\hline Weeding & 30 & 1st and 2 nd yr & (610 USD/ha on 3rd year) & \\
\hline Monitoring & 3 & 3rd till last yr & & \\
\hline \multirow[t]{2}{*}{ Supervision } & 75 & 1st year & (5 USD/ha from 2nd to last year) & \\
\hline & $\mathrm{USD} / \mathrm{m}^{3}$ & & & Hakkila, 1994 \\
\hline Harvesting and transport cost & 10.3 & Last year & (During harvesting) & Interviews, 1996 \\
\hline Reforestation fee & 1.5 & Last year & (During harvesting) & World bank, 1993 \\
\hline Fixed Cost & USD/year & & & Rissanen, 1995 \\
\hline Fixed establishment costs & 15,525 & 1st year & (During planting) & \\
\hline Fixed harvesting costs & 53,865 & Last year & (During harvesting) & \\
\hline Depreciation of machinery & 800 & First 5 years & & \\
\hline Investments & USD & & & Rissanen, 1995 \\
\hline Buildings & 12,500 & 1st year & & \\
\hline Buildings & 8300 & 1 year & Before harvesting & \\
\hline Fire protection & 2450 & 1st and 6th yr & & \\
\hline Machinery and equipment & 4100 & 1st year & & \\
\hline Roundwood price & $\mathrm{USD} / \mathrm{m}^{3}$ & & & Interviews, 1996 \\
\hline Acacia mangium & 20.00 & Roadside price & & \\
\hline
\end{tabular}

\subsection{Evaluation of the Costs of the Use of Sludge}

The quantitative hypothesis is that the application of recycled nutrients results in the same or higher financial profitability compared with the use of mineral nutrients in the production of fast-growing pulpwood in the reference research.

The nutrient contents in the sludge are estimated first, and nutrient requirements in tree growing are defined based on the previous studies. Next, the required sludge volume for the adequate fertilization impact is calculated. The related costs are estimated according to cost data collected through different secondary sources while also applying the figures from agriculture. This research procedure leads to the valuation of the total cost when replacing a part of artificial fertilizers with nutrient-rich sludge in the production of fast-growing pulpwood.

The relevant cost factors on the use of sewage sludge spread on farmlands were adopted from Bresters et al. [22]. It was assumed that no costs resulted from the analyses of sludge and soil quality (see Chapter 5.3 Regulatory concerns). Investments included machinery for spreading were excluded and replaced by the hiring costs of the equipment, which was included in the spreading costs. The cost adjustments can be reassessed if up-dated data is available.

The planting must be a continuous process to guarantee a steady wood flow to the industrial site. The harvested area is planted after the logging, and the sludge is spread 
frequently to each planting site. No sludge storage was considered in this analysis. Consequently, storage investment and operating costs as well as transport costs from storage to farms were excluded in the analysis, as no realistic data was available. Currently, the sludge treatment causes waste management costs for the industries. Hence, the recycling of a part of the sludge can lead to a positive economic result in the circular bioeconomy model. Administrative expenses were not considered, either. However, the supply of triple phosphate was proved to be important for the initial period of planting A. mangium [23], thus the cost of this artificial fertilizer was included in the model.

The mill sludge application in the establishment of a fast-growing plantation covered in this model include (1) transport cost from pulp and paper mill to plantation, (2) expenses for sludge application, and (3) associated costs of the additional use of triple phosphate (optional). The related costs were estimated based on the publicly open, secondary data specified in Chapter 3.2.

\subsection{Financial Methodology}

\subsubsection{Discounted Cash Flow}

The financial profitability was analyzed by applying discounted cash flow. The project period was 18 years including 1 planting round of seedlings and 3 coppices. Total costs and revenues for the project area of 1000 hectares were estimated for the entire time span. The financial analysis results in the net present value (NPV) and internal rate of return (IRR) to measure the financial profitability. The required average IRR for an industrial investment is commonly $13 \%$. For example, the European Union requires an average rate of return of $12.2 \%$ for investment projects sponsored (Florio, 2000), and Finnish publicly listed companies require a rate of return of 10 to $16 \%$ [24,25].

\subsubsection{Fixed Prices vs. Variable Prices}

The input prices were gathered from different public sources from different years. Consequently, the price level was synchronized. The unit costs of inputs were mainly gathered from Indonesia but valued as US dollars. Due to this, inflation of consumer prices (annual \%) (Inflation based on the consumer price index refers to the annual change in the costs. The Laspeyres formula is commonly applied in this context.) for Indonesia [26] and the United States [27] were applied (Figure 3).

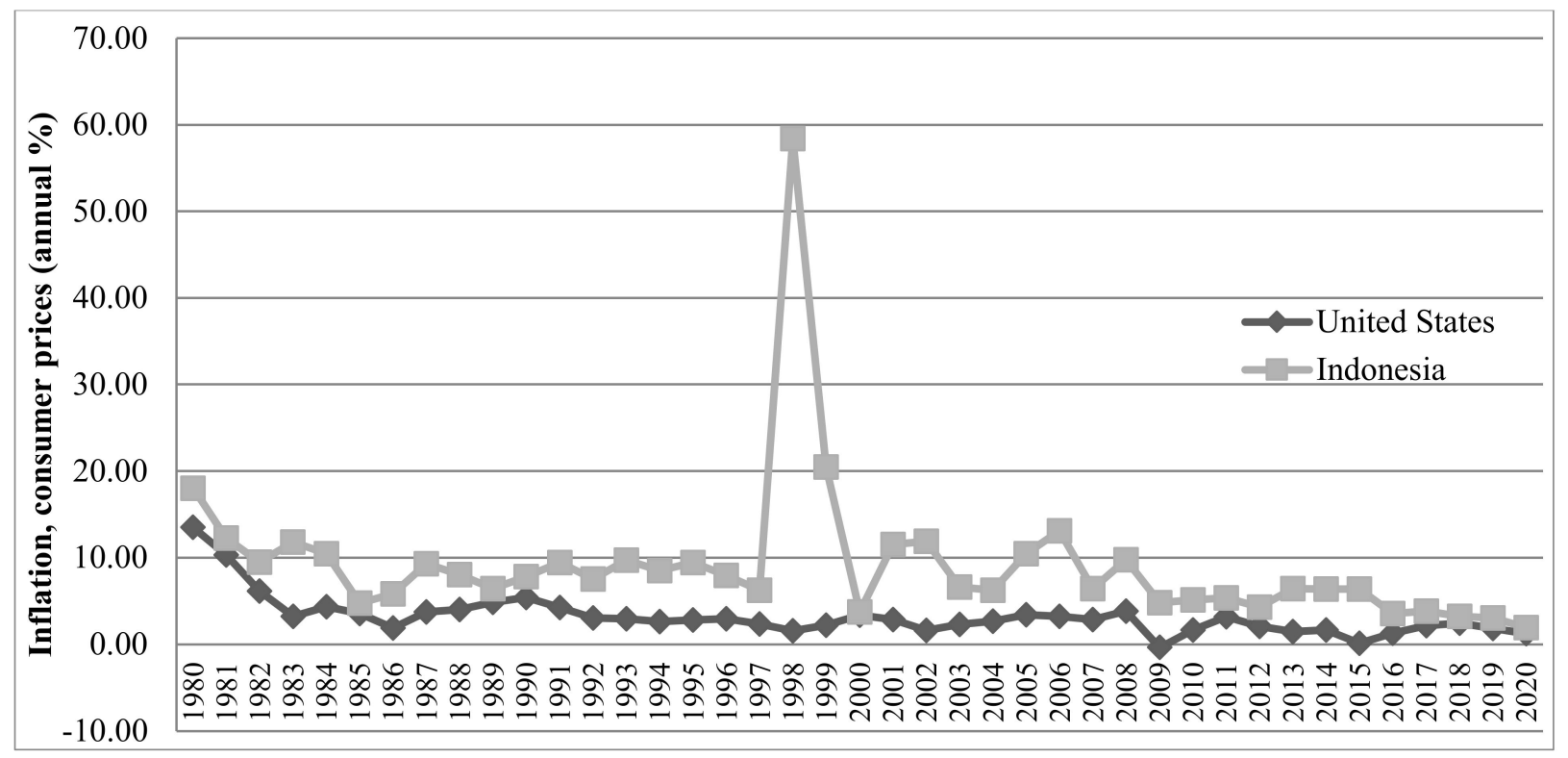

Figure 3. Inflation of consumer prices (annual \%) in Indonesia and the United States [26,27]. 
The price level adjustment was challenging due to inflation peak in Indonesia in the late 1990 's when the reference study was carried out that biases the long-term price estimations. We aimed at reaching a realistic understanding of the price level fluctuations by selecting some costs and adjusting them with proper inflation rates in order to assess the reliability of the applied adjustments (see Section 3.3).

\subsection{Qualitative Sustainability Analysis}

Sustainability dimensions of the proposed circular bioeconomy model were analyzed qualitatively in order to layout the comprehensive benefits of the model. A thematic qualitative text analysis [28] was adjusted for the material applied in this study. The qualitative analysis was integrated with sustainability approaches aiming at researching what the environmental, economic, and social benefits of the circular bioeconomy model were. We collected and identified relevant data based on a literature review. A sustainability analysis applying the triple value model, a systems-thinking approach by Fiksel et al. [29], was also conducted. The identified benefits in concrete detail were categorized into local and global levels and sub-categorized into various dimensions within environmental, economic, and social approaches.

\section{Financial Analysis}

\subsection{Nutrient Contents}

The nutrient contents of the used materials were analyzed based on the dry matter (\% dry), the carbon to nitrogen $(\mathrm{C}: \mathrm{N})$ ratio, and the total amounts of nitrogen, phosphorus, and potassium (NPK). These are the main nutrients in tree growing. Other specific forms of the chemical compounds and other particles were excluded from the analysis. The data was based on the case of a combined paper mill's biosolids [21], as it contains higher degrees of the needed nutrients and a lower C:N ratio (see Section 5: $\mathrm{N}$ immobilization for further discussion), compared with primary and de-inking paper mill biosolids [21]. The average data was applied for the calculation, first from the average of each selected parameter within its source and, secondly, the average of the three different sources (Table 3).

Table 3. Estimates of nutrient contents from the combined paper mill biosolids.

\begin{tabular}{lcc}
\hline & Characteristic & Amount \\
\hline Dry matter (\% dry) & 30.48 \\
C:N ratio & $25.83: 1$ \\
Total N ( $\mathrm{g} \mathrm{kg}^{-1}$ dry) & 16.20 \\
Total P ( $\mathrm{g} \mathrm{kg}^{-1}$ dry) & 2.92 \\
Total K ( $\mathrm{g} \mathrm{kg}^{-1}$ dry) & 2.44 \\
\hline
\end{tabular}

\subsection{Application Rate and Cost Estimates}

The nutrient requirements were estimated based on Adjers and Luukkanen [23], applying the suitable combinations of nutrients (NPK) for A. mangium (Table 2). A short-rotation wood plantation requires additional fertilization simultaneously with the planting in order to strengthen the initial growth. A pulpwood plantation seldom requires further fertilization later on. Consequently, the fertilization costs were allocated to the first project year. The hypothetical sludge spreading followed the above-mentioned fertilization program of an industrial pulpwood plantation, and thus the nutrient requirements were defined in annual rates. Table 4 shows the required sludge volumes related to the estimated nutrient contents (Table 1) in dry matter to reach the adequate application rates of the nutrients. The total amount of sludge of $2000 \mathrm{~kg}$ dry was estimated to result in an application rate of sludge of approximately $6.56 \mathrm{Mg} / \mathrm{ha}$ (wet) in the first year of each annual plantation containing the required dry solid contents of NPK. 
Table 4. Amounts of sludge.

\begin{tabular}{lccc}
\hline Characteristic & $\begin{array}{c}\text { Defined Annual Rate of Nutrients } \\
\text { (kg/ha) }\end{array}$ & $\begin{array}{c}\text { Required Amount of Sludge } \\
\text { (kg Dry) }\end{array}$ & $\begin{array}{c}\text { Calculated Amount from the Sludge } \\
\text { Amount of 2000 kg (kg Dry) }\end{array}$ \\
\hline Total N & 22 & 1358 & 32 \\
Total P & 20 & 6853 & 6 \\
Total K & 10 & 4107 & 5 \\
\hline
\end{tabular}

The sludge amount at $2000 \mathrm{~kg}$ was approximated to provide moderate amounts of all of the required nutrients. The required total amounts of the phosphorus or potassium finally exceeded the final amounts of nitrogen to the level with risk of the negative impacts on the environment [30]. Phosphorus can be supplemented by the complementary mineral fertilizer. For example, Adjers and Luukkanen [23] recommended to supply triple phosphate as a supplement of $P$ at the rate of about $5-30 \mathrm{~kg} / \mathrm{ha} P$ in Kalimantan, Indonesia.

The growth rate is sensitive to proper fertilization. Hence, a proper estimate of the sludge application rate considering sludge properties, crop nutrient requirements, and the frequency of application is essential for a successful plantation operation. An average growth rate is applied in this analysis, as the final amount of sludge and the application rate needed for the designed plantation are only relevant to the cost estimates of sludge transport and application.

\subsubsection{Application Cost}

A few previous studies [31,32] estimated the cost of USD 32 per dry ton, including both land spreading and transporting, as the sludge was hauled from municipal wastewater treatment plants and applied on farmlands by the same truck with a simple land-spreading system.

Another research group [33] evaluated the costs of four liquid manure field application methods, and the average cost per hectare of every available method was approximately USD 31.51 in Idaho, USA. The method with the highest cost was a single knife injection unit with no nurse tanker support, amounting to USD 37.82/ha.

The previous studies showed the application cost per hectare to be lower compared with the cost per amount of sludge, as it does not include transportation. Moreover, the injection method has greater advantages compared with land-spreading due to lower occurrences of odors and sludge loss possibly caused by erosion and nutrient loss to the atmosphere [31]. Here, the analysis is based on the liquid manure spreading technique or a similar application. The application cost of liquid manure with the highest cost method from the reference study was used as the application cost of pulp and paper mill sludge and considered the transport cost separately. We did not relate the availability of the plant uptake caused by the application method as a fixed growth rate was applied.

\subsubsection{Transport Cost}

The final report of from Waste to Traffic Fuel projects indicated the average transportation cost of municipal sludge by haul truck to be EUR $4 / \mathrm{t}$ or approximately USD $4.8 / \mathrm{t}$ in selected cases in Finland [34]. An Indonesian case study, PT. Pindo Deli Pulp and Paper Mills in Ciampel-Karawang, West-Java, indicated the cost of USD 5/t for transporting sludge to kiln fuel at cement plants [35].

The examples in Finland and Indonesia showed the sludge transport costs being relatively stable in different places, in different years. Based on this, the estimated cost of USD 5/t for the sludge transport by truck cost was applied here. The transport cost may vary according to the transport distance, the number of operating days per year, and whether the transport is self-operated or outsourced [36,37]. The transport cost here responded linearly to the amount of sludge being hauled, other parameters with incomplete information were excluded in the analysis. 


\subsubsection{Triple Phosphate Cost}

FAO [38] presented the prices of phosphate fertilizers in the form of TSP (Triple superphosphate (46 percent of $\left.\mathrm{P}_{2} \mathrm{O}_{5}\right)$ ) in combination with SP-36 (Superphosphate (36 percent of $\left.\mathrm{P}_{2} \mathrm{O}_{5}\right)$ ) in Indonesia between 1990 and 2001. The TSP/SP-36 prices peaked in 1995 up to USD $228.7 /$ ton and falling to USD $87.1 /$ ton in 1998. The price level fluctuated marginally between 2000 and 2001. Based on the references, the average price of USD $156.4 /$ ton was applied during the entire project period. The assumed average price of the TSP/SP-36 was based on the TSP price. Based on the available price data, the triple phosphate treatment is hereinafter referred to as the additional use of TSP. The total cost of TSP application considered the spreading cost for TSP, too. The application rate and the related cost estimates of the use of pulp and paper mill sludge are summarized in Table 5 .

Table 5. Summary of the estimated costs for the use of pulp and paper mill sludge.

\begin{tabular}{lccc}
\hline \multicolumn{1}{c}{ Factor } & Unit & Cost & Source \\
\hline Application rate & Mg/ha (wet) & 6.56 & Calculated \\
Application cost & USD/ha & 37.82 & {$[33]$} \\
Transport cost & USD/ton & 5 & {$[35]$} \\
TSP price & USD/ton & 156.4 & {$[38]$} \\
TSP spreading cost & USD/ha & 12.36 & {$[39]$} \\
\hline
\end{tabular}

\subsection{Inflation Correction}

The applicability of inflation correction was estimated with the roundwood price and Indonesian consumer prices in order to investigate the reliability of the main parameters by Kosonen et al. [16]. The roundwood price of USD $20 / \mathrm{m}^{3}$ in Indonesia in the year 1996, at the time of data gathering of the reference study, corresponded in the price of approximately USD $111.7 / \mathrm{m}^{3}$ in 2013 when applying the inflation rates followed Indonesia's inflation and consumer prices (annual \%) between 1996 and 2013 [26].

The peak in Indonesian consumer prices in 1997-2000 biased the inflation correction in this analysis (Figure 4). The prices increased as no deflation rate was applied. Furthermore, no correspondence was observed with the changing global prices of wood pulp [40], which had been fluctuating (Figure 3). The unit of roundwood prices in Indonesia (USD $/ \mathrm{m}^{3}$ ) was diverse from that of the global wood pulp prices (USD/MT). Consequently, the trend of changes was considered in the comparison. The adjustment of the main cost data of the reference study [16] with Indonesia's inflation rates in the year of this study had not been reliable due the changing economic development in the hypothetical study area.

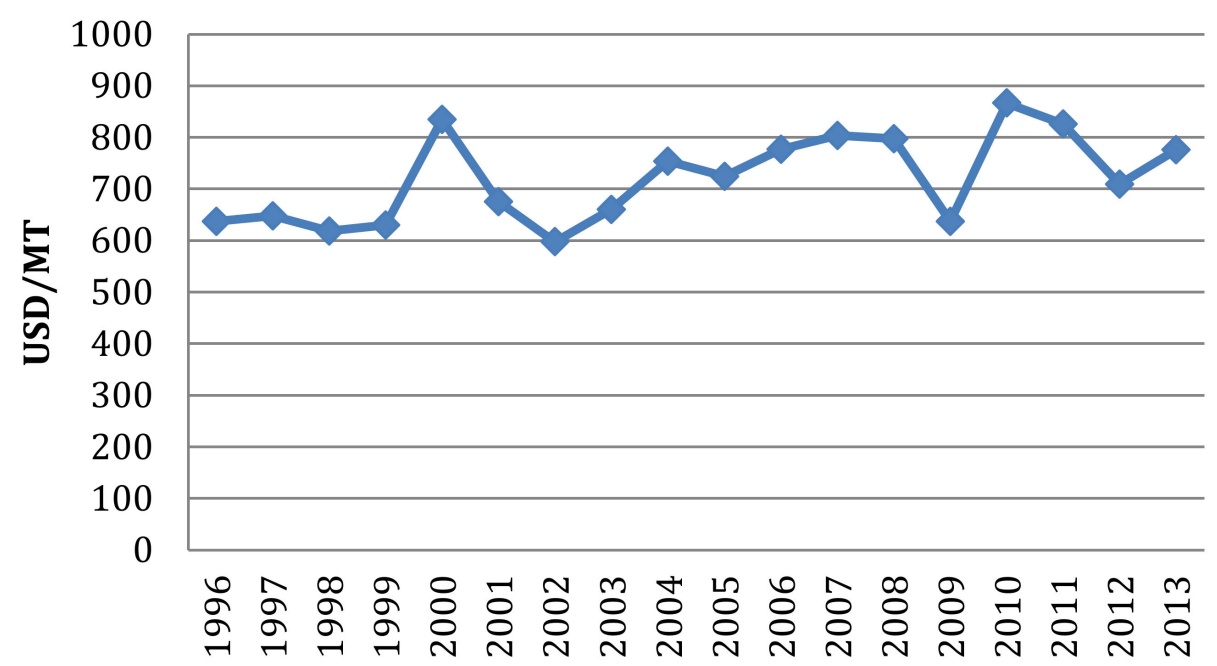

Figure 4. Pulpwood world prices in 1996-2013 adjusted according to [40]. 
The US inflation rates were applied to the sludge application cost of USD 37.82/ha in the data gathering year of 2014 by Gray et al. [33] to adjust for inflation since 1996 and to compare with the original fertilization cost of USD 97/ha in 1996 in order assess the reliability of the estimated costs in Chapter 3.2.

The adjustment resulted in the application cost of USD 24.45/ha. However, we considered this cost after the adjustment to be unreasonable, as it was relatively low and might underestimate the total fertilization cost. Hence, we did not adjust this cost or the other cost parameters with inflation rates. We assumed that the inflation rates have a small impact on the estimates of the total cost when using recycled nutrients as the fertilization cost reference.

\subsection{Estimated Fertilization Cost}

The fertilization costs were classified into three groups following the estimated associated costs presented in Section 3.2 following Utanun's [20] research setting. The three different fertilization cost scenarios designed for the analyses are described below.

Scenario (1)—Base case: the fertilization cost based on the reference study. The cost breakdown was not explained and considered;

Scenario (2)-Use of sludge. The total costs include the transport and application;

Scenario (3)-Use of sludge with TSP fertilizer. The total cost covers transport and application costs, the price of TSP, and TSP application costs.

The total estimated fertilization cost of each scenario was summarized in Figure 5 and Appendix A, Table A1. Figure 4 describes the share of reduction in scenarios 2 and 3 related to scenario 1 .

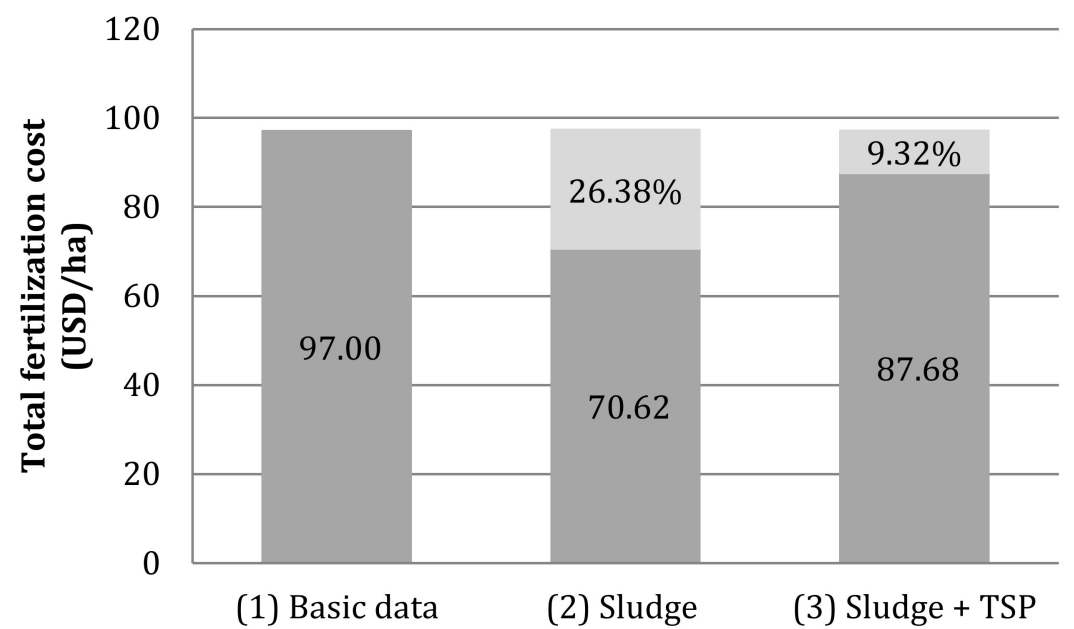

Figure 5. Estimates of total fertilization cost.

\subsection{Financial Profitability}

The net present value without discounting scenario 1 was approximately USD 222,900. The result diverged from that of the original reference model, USD 250,000, due to different calculating tools and the uncertainty of basic information. The net cash flow of the total production of fast-growing pulpwood with the basic data (scenario 1) in the total production time of 18 years generated a positive cash flow after the first 8 years, i.e., after harvesting of the first planted 100 has (Figure 6). 

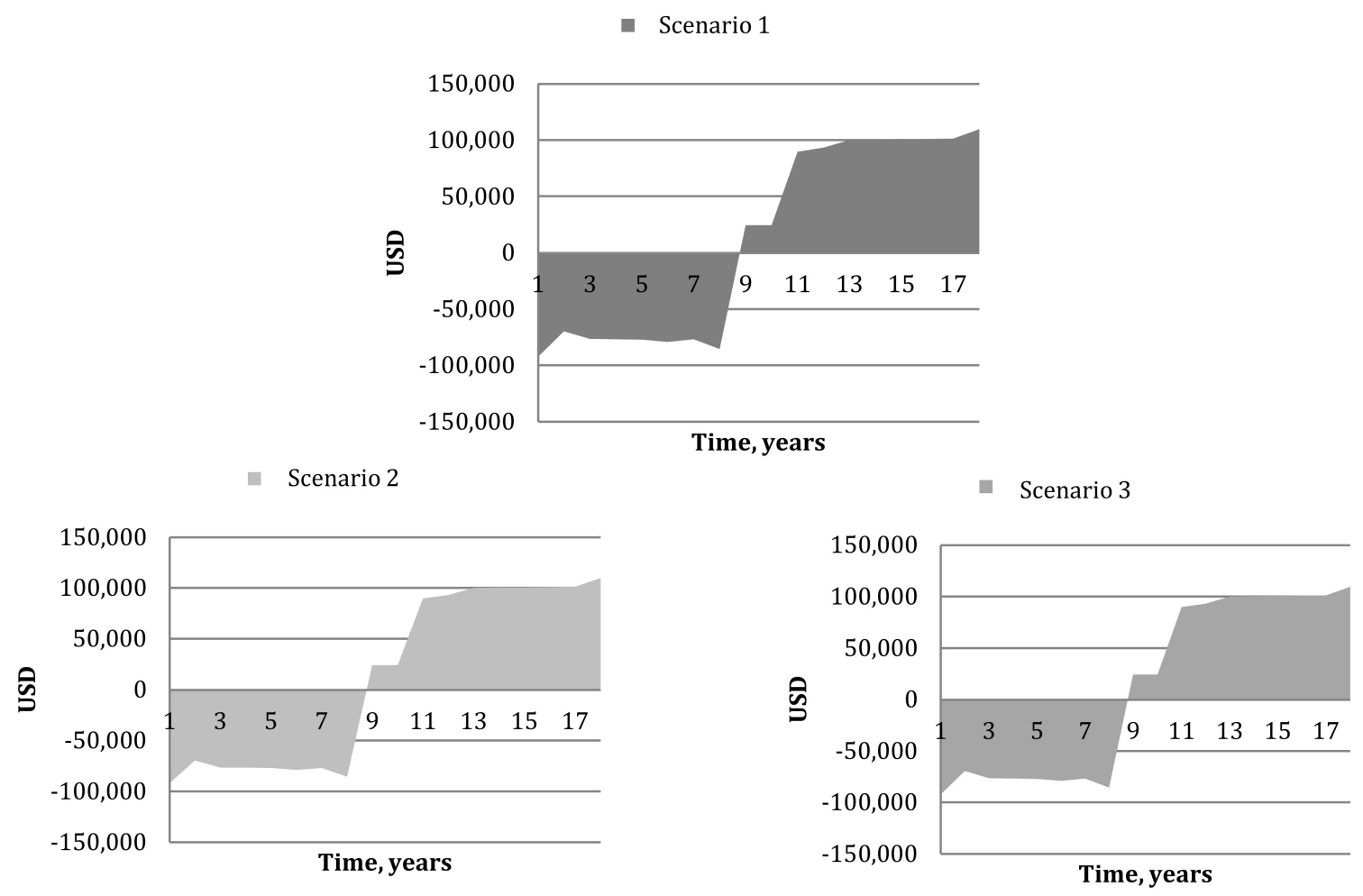

Figure 6. Net cash flow without discounting the total fast growing pulpwood production in 18 years.

Similarly, the other two scenarios generated a similar curve reflecting NPVs with a zero percent discount when applying the estimated fertilization costs of scenarios 2 and 3. The net present values (NPVs) at zero percent discount and internal rates of return (IRRs) of all of the scenarios are presented in Table 4, the last row showing the average of both values. Table 6 illustrates the NPVs of scenarios 1, 2, and 3 with $0,5,11$, and 20\%, respectively.

Table 6. NPVs and IRRs of the different scenarios.

\begin{tabular}{|c|c|c|c|c|}
\hline $\begin{array}{l}\text { Fertilization } \\
\text { Scenario }\end{array}$ & \multicolumn{2}{|c|}{$\begin{array}{c}\text { NPV—0\% Discount } \\
\text { ('000 USD) }\end{array}$} & \multicolumn{2}{|c|}{$\begin{array}{l}\text { IRR } \\
(\%)\end{array}$} \\
\hline 1 Basic data & \multicolumn{2}{|c|}{222.90} & \multicolumn{2}{|c|}{3.17} \\
\hline 2 Sludge & \multicolumn{2}{|c|}{249.28} & \multicolumn{2}{|c|}{3.61} \\
\hline 3 Sludge + TSP & \multicolumn{2}{|c|}{232.22} & \multicolumn{2}{|c|}{3.32} \\
\hline Average & \multicolumn{2}{|c|}{248.18} & \multicolumn{2}{|c|}{3.63} \\
\hline \multicolumn{5}{|c|}{ NPVs at $0,5,11$, and 20 percent } \\
\hline & \multicolumn{4}{|c|}{ NPV ('000 USD) } \\
\hline$\%$ Discount & $0 \%$ & $5 \%$ & $11 \%$ & $20 \%$ \\
\hline 1 Basic data & 222.90 & -79.64 & -204.82 & -231.06 \\
\hline 2 Sludge & 249.28 & -59.28 & -189.29 & -220.00 \\
\hline 3 Sludge + TSP & 232.22 & -72.44 & -199.33 & -227.15 \\
\hline
\end{tabular}

\subsection{Sensitivity Analysis}

The first sensitivity analysis investigated the sensitivity of the estimated fertilization costs of scenarios 2 and 3 related to the application rate. The total fertilization costs were based on the increase and decrease in the application rate from the base case of $6.56 \mathrm{Mg} / \mathrm{ha}$ (wet) by $10 \%$ and $25 \%$, resulting in scenarios 2 and 3 .

The second sensitivity analysis analyzed the sensitivity of the profitability, i.e., IRR, related to the changes in fertilization costs (Table 7). The different fertilization scenarios 
based on the data in Table 6 and the total fertilization costs in Table 8 is illustrated in Figure 7.

Table 7. Sensitivity analysis of IRR to total fertilization cost.

\begin{tabular}{lccccc}
\hline & \multicolumn{5}{c}{ IRR (\%) } \\
\hline Total Fertilization Cost, Change & $\mathbf{- 2 5 \%}$ & $\mathbf{- 1 0 \%}$ & $\mathbf{0 \%}$ & $\mathbf{1 0 \%}$ & $\mathbf{2 5 \%}$ \\
\hline (1) Basic data & 3.57 & 3.33 & 3.17 & 3.01 & 2.78 \\
(2) Sludge & 3.91 & 3.73 & 3.61 & 3.49 & 3.31 \\
(3) Sludge + TSP & 3.69 & 3.47 & 3.32 & 3.18 & 2.96 \\
\hline
\end{tabular}

Table 8. Sensitivity analysis of total fertilization cost to application rate.

\begin{tabular}{cccccc}
\hline & \multicolumn{5}{c}{ Total Fertilization Cost (USD/ha) } \\
\hline Application Rate Changed & $-\mathbf{2 5 \%}$ & $\mathbf{- 1 0 \%}$ & $\mathbf{0}$ & $\mathbf{1 0} \%$ & $\mathbf{2 5 \%}$ \\
\hline 2 Sludge & 62.42 & 67.34 & 70.62 & 73.91 & 78.83 \\
3 Sludge + TSP & 79.48 & 84.40 & 87.68 & 90.96 & 95.88 \\
\hline
\end{tabular}

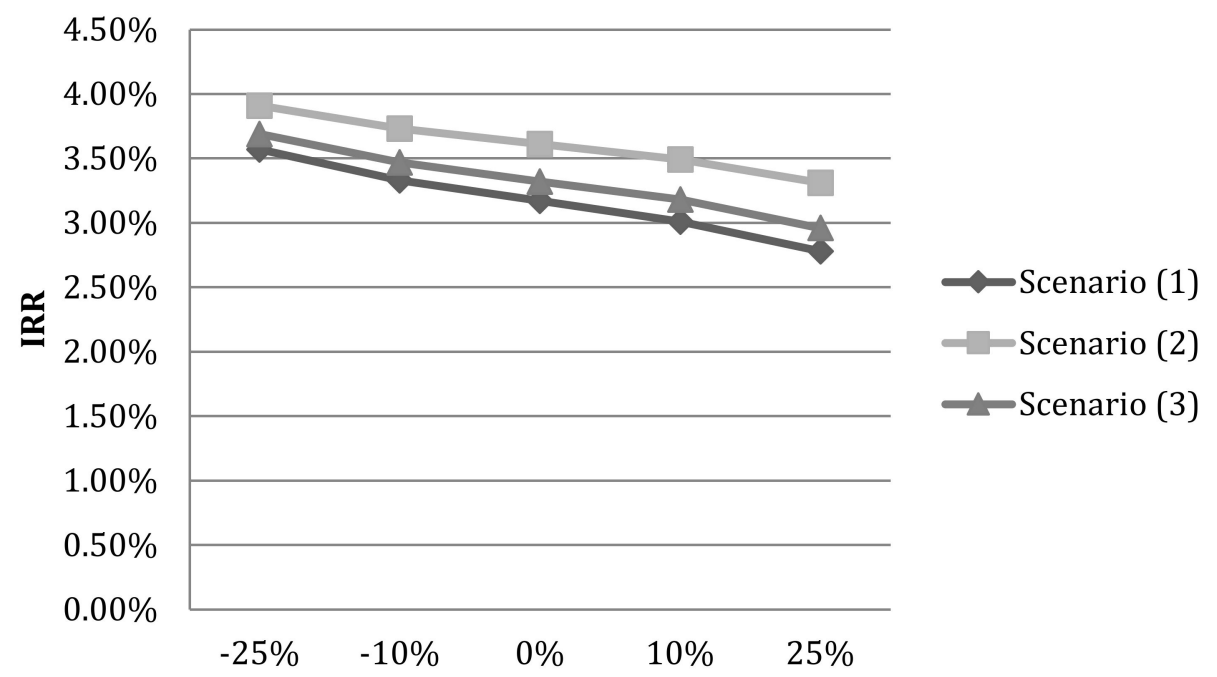

Figure 7. Sensitivity analysis of IRR to total fertilization cost.

The third sensitivity analysis assessed the sensitivity in regarding to MAI. Here, MAI was increased by $20 \%$ from the basic case of $25 \mathrm{~m}^{3} /$ ha (Table 9 ).

Table 9. Sensitivity analysis of IRR to MAI.

\begin{tabular}{|c|c|c|c|}
\hline \multirow[b]{2}{*}{ Fertilization Scenario } & \multicolumn{3}{|c|}{ IRR (\%) } \\
\hline & $\begin{array}{l}\text { MAI = } 25 \mathrm{~m}^{3} / \mathrm{ha} \\
\text { (Basic Analysis) }\end{array}$ & MAI $=30 \mathrm{~m}^{3} / \mathrm{ha}$ & MAI $=36 \mathrm{~m}^{3} / \mathrm{ha}$ \\
\hline 1 Basic data & 3.17 & 6.87 & 10.37 \\
\hline 2 Sludge & 3.61 & 7.66 & 11.23 \\
\hline 3 Sludge + TSP & 3.32 & 7.35 & 10.91 \\
\hline
\end{tabular}

Furthermore, the MAIs and roundwood prices at the road side were analyzed to reach an IRR of $13 \%$ in the three different scenarios keeping the other parameters at the same level (Table 10). 
Table 10. Minimum MAI or roundwood price to reach an IRR of $13 \%$ in the scenarios.

\begin{tabular}{lcc}
\hline Fertilization Scenario & $\begin{array}{c}\text { MAI } \\
\left(\mathbf{m}^{\mathbf{3}} \mathbf{/ h a}\right)\end{array}$ & Roundwood Price (USD/m $\left.\mathbf{~}^{\mathbf{3}}\right)$ \\
\hline Base case & 25.00 & 20.00 \\
\hline (1) Basic data & 41.45 & 25.40 \\
(2) Sludge & 40.38 & 23.47 \\
(3) Sludge + TSP & 41.07 & 25.05 \\
\hline
\end{tabular}

\section{Incorporation of the Circular Bioeconomy Model with Sustainability Analysis}

This section presents a qualitative analysis with a sustainability perspective regarding the use of recycled nutrients from pulp and paper mill sludge in industrial-scale biomass production. The section assesses qualitative the potential benefits of Scenarios 2 and 3 from various perspectives. Due to the limited data, the expected benefits are integrated qualitatively into the scenarios. Figure 8 illustrates a holistic view of the qualitative values in the triple value model.

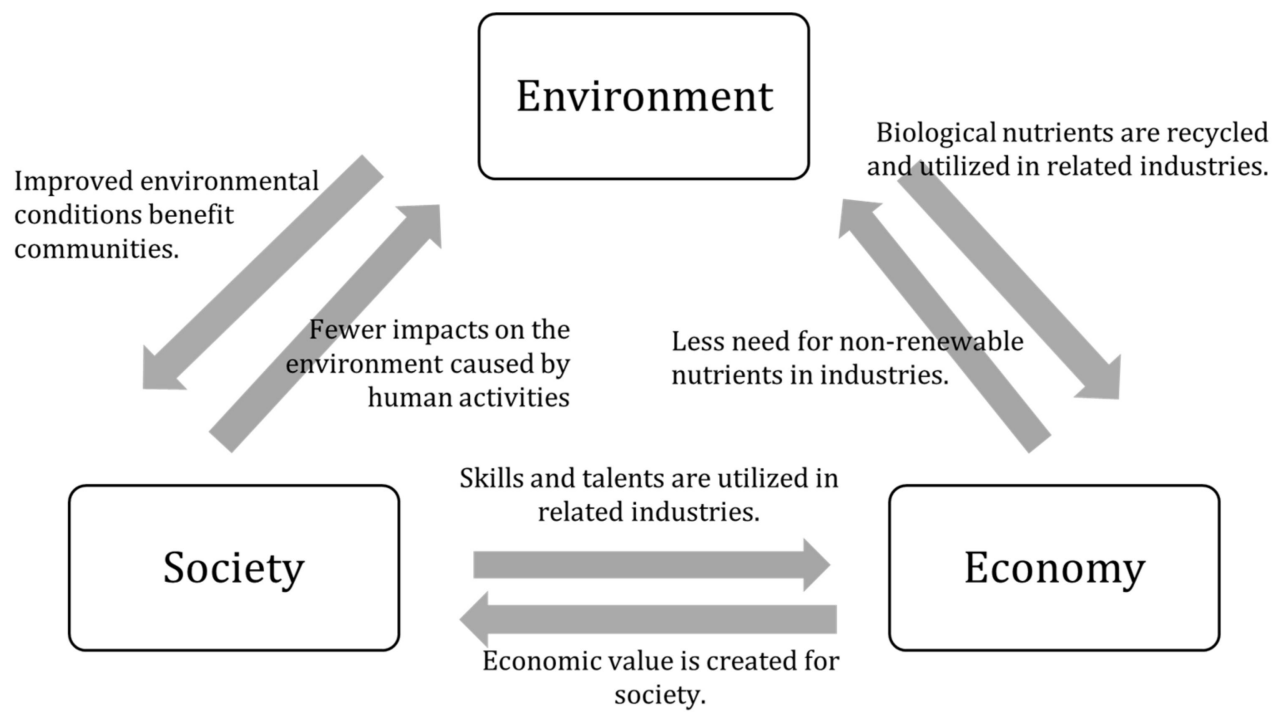

Figure 8. Systems approach to sustainability by the use of recycled nutrients, adjusted according to [29].

Some environmental, social, and economic issues related to the nutrient recycling within biomass production and processing were reviewed qualitatively at local and global level based on previous studies in order to illustrate the total value potential of the Scenarios 2 and, especially, 3 and, hence, the entire circular bioeconomy approach from the social and environmental perspective (Table 11). 
Table 11. Potential benefits of applying recycled sludge-origin nutrients in biomass production.

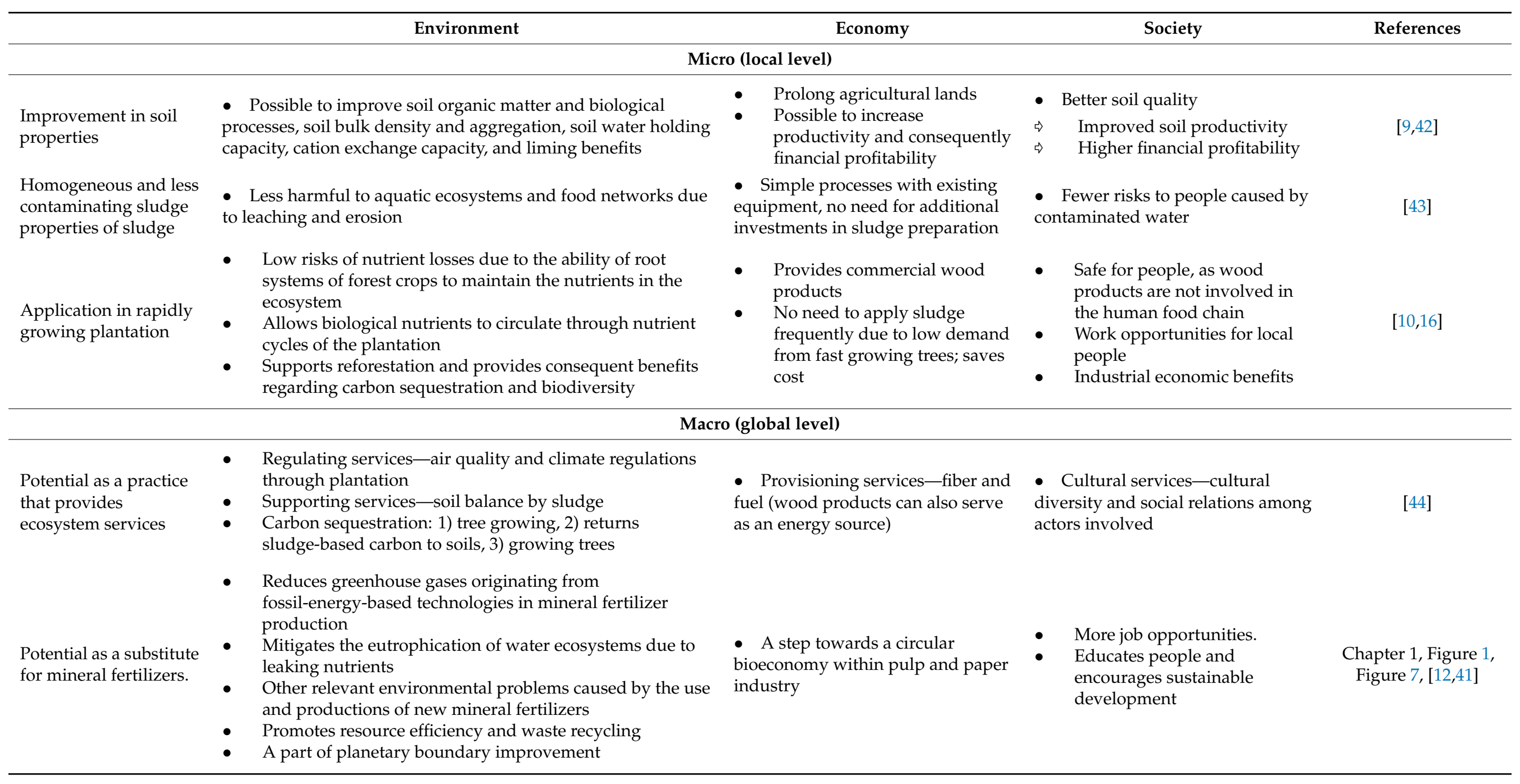


The main expected, positive impacts of the application of recycled nutrients are an improved soil production capacity due to increased nutrients and organic material, decreased leaking of nutrients into water ecosystems and, consequently, better water quality, and the intensified carbon sequestration of the soil. The sludge from the biological treatment as well as the wood fiber containing sludges separated from the pulp and paper processes are homogeneous and cleaner compared to the municipal wastewater. The PPI wastewaters and sludges could be utilized relatively safely, even though some cleaning processes are necessary, as additional nutrient sources to mineral fertilizers and as soil improvement materials amendments in agriculture and forest plantation production. The recycling of carbon and nutrients has positive impacts on the mitigation of climate change, as carbon is sequestrated into soil in addition into the produced biomasses. Similarly, the leaking of nutrients and organic material into the water ecosystems decreases on good quality sites. The recycling of nutrients and carbon are also critical for the soil production capacity $[12,41]$ in terms of more efficient nutrient sequestration by the vegetation whether the biomass is processed as paper, food, or energy.

The positive environmental impacts have commonly positive social reflections at the local level, such as increased and diversified working opportunities for local people and the consequent income sources. Especially, the improve soil quality due to the application of carbon-rich recycled material is expected to increase the harvest level in the long run. The environmental quality and various ecosystem services also improves the quality of life of local populations in terms of air and water quality. The potential social and environmental benefits were not quantified within this research setting due to limited available data. A case study approach applying a comprehensive socioeconomic and environmental economic analyses can allow for the quantification of social and environmental benefits in the future studies.

\section{Discussion}

\subsection{Financial Profitability and Generalizability of the Results}

The original data was gathered from a long-term, profoundly documented trial work in South Kalimantan, Indonesia, from 1980 to 1995 [16,18,23,41]. Hence, the data basis was considered solid and reliable, even though updating was needed. Furthermore, new data sets, especially based on industrial operations, are commonly challenging to obtain due to confidentiality. The availability of the unique data from various places covering the same time span is a challenge in global studies. The inflation rate of the 2000s has stayed relatively steady indicating little changes in the operational cost level after the fluctuation period. Based on this trend, some cost data originating from different years were applied in the analysis in order to build a comprehensive financial model. The variety of data sources may lead to a minor inaccuracy in the analysis. However, this approach allowed the financial model to be built and to be completed with higher quality data later.

The direct financial profitability remains relatively low both in the original analysis and the updated version when replacing a part of the artificial fertilizers with sludge-based recycled nutrients. The profitability analysis with the conservative estimate of a MAI of $25 \mathrm{~m}^{3} /$ ha resulted in an IRR level of 3-4\% in 1997. The application of recycled nutrients had no direct impact on the financial profitability and result in IRRs of the same level, which are well below the industrial IRR requirement of $13 \%$.

The profitability of the recycled model is most sensitive to the MAI and sales price than the tested fertilization approaches. The wood production, i.e., MAI, can be improved through environmental conditions, such as soil and climate, and intensive plantation management with properly timed fertilization, weeding, and thinning. Intensive management is crucial, especially on poor sites.

Furthermore, trials and studies involving soil tests and the selection of appropriate tree species and site preparation treatments can lead to higher yields per hectare. Otsamo et al.'s [42] findings emphasized the initial site preparations in the reforestation of Imperata cylindica grasslands in Indonesia. The treatment improved the growth of four promising 
tree species in the study trials. For example, the highest MAI of A. mangium, $36.7 \pm 9.9 \mathrm{~m}^{3}$, was reached by combining the mechanical site preparation method, plowing, and NPK fertilizing. With the highest number of this MAI range, it is possible to reach an IRR of more than $13 \%$ in all of the scenarios in this study (Table 8 ).

The hypothetical calculations showed that the direct financial profitability remains at least at the same level as in the basic cases based on the use of mineral fertilizers if no further parameters are included in the analysis. The result indicated financial profitability as the estimated costs of recycling nutrients per hectare were lower compared with the mineral fertilizer cost based on the reference study. Both financial indicators-NPVs and IRRs - in scenarios 2 and 3 were consequently higher compared with scenario 1 , as the fertilization cost was the only factor being adjusted in the analysis. Therefore, pulp and paper mill sludge can generally replace a part of mineral fertilizers, resulting in lower total costs.

The costs of the utilization of sludge in agriculture or forestry is composed of transport and spreading costs. Generally, fertilization was not a critical cost element in the financial profitability analysis. An increase of $25 \%$ in the application of sludge increased the total fertilization cost but has only marginal impact on the IRR indicator. The outcome favors the application of sludge on forestlands to supplement artificial fertilizers. The sludge quality can be improved during or after the wastewater treatment processes leading to the higher growth rate in plantations (Benedetti, 2014). The consequent higher financial profitability covers the costs of additional sludge treatment.

The research setting was based on a hypothetical case from Indonesia, relying on a long-term field research conducted in the 1980s and 1990s [16-19,23,42]. Indonesian circumstances are promising for fast growing biomass production. In addition, the location in close proximity to the vast Southeast Asian markets for various biomass-based products is attractive for large-scale operations and the industrial processing of raw materials. The major challenges are related to the complex contracts on land use overlapping with the traditional rights of indigenous people and other socioeconomic factors framed beyond the scope of this study.

The tentative research findings are applicable in various types of biomass production, for example, wood and oil palm, largely in Southeast Asia, to understand the potential of circular solutions. The operational model is also applicable at global level under similar conditions when assessing various circular models for biomass productions: for example, the utilization of residuals as fertilizers and soil improvement material in various types of agrifood plantations in Brazil. The operational model can also be applied in the northern hemisphere. For example, Joona [12] presented the utilization of the pulp and paper sludge to agricultural cultivations in Finland. Detailed analyses with site-specific parameters are required for further analysis and, for example, investment and other operational decisions in practice in different operation environments.

The research setting was framed to (1) build a generalizable and operational model based on publicly available data to promote circular bioeconomy and (2) to investigate the financial profitability of the application of the pulp and paper mill sludge as an alternative input, i.e., recycled fertilizer that replaces artificial fertilizers, in biomass productions. The financial analysis excluded further environmental and social analysis and the impact of variety of factors on financial NPV and social NPV. The potential value of larger environmental benefits was excluded in this analysis. The research scope needs to be enlarged in the future in order to comprehensively understand future trends and the performance environments as well as impacts of local societies. In addition, tools, for example Monte Carlo simulation are recommendable to test to include uncertain future data, especially the related social issues, in the analysis. Furthermore, a multicriteria approach could be a potential future research pathway in incorporating social and environmental qualitative analysis with financial scenarios. 


\subsection{N Immobilization}

$\mathrm{N}$ immobilization is a consequence of the use of organic materials with $\mathrm{C}: \mathrm{N}$ ratios of more than to 20-30:1 [9,45]. Here, the assumed C:N ration of 26:1 was applied in the analyses remaining below the critical level. The risk of $\mathrm{N}$ immobilization remained reasonable within the prevailing assumption. The risk of $\mathrm{N}$ immobilization in terms of the amount and duration could be considerably higher if primary and de-inking paper mill biosolids from the third source alone with a C:N ratio of about 288:1 had been applied [21,46]. Zibilske [47] ended up with the $\mathrm{N}$ immobilization of the application rates of 17-267 $\mathrm{g}$ sludge $\mathrm{kg}$ soil $^{-1}$ for even 250 days if the primary sludge with a very high C:N ratio of 480:1 was used. The $\mathrm{N}$ immobilization can be avoided to some extent by leaving the treatment area for a certain period after the sludge spreading. This would balance the C:N ratio before planting crops [48]. Furthermore, $\mathrm{N}$ can be supplemented by another $\mathrm{N}$ source, such as standard $\mathrm{N}$ fertilizer, to compensate for the low $\mathrm{N}$ contents in the sludge used [49].

Even though pulp and paper mill sludge contain useful nutrients for tree growth, their uses in agriculture and forestry may include some drawbacks. It is recommendable to analyze the precise sludge characteristics and evaluate the possible impacts on soil, plants, and the surrounding environment. An additional sludge improvement or an approach to overcome immobilization is required when the mass is not appropriate for use in tree plantations. Otherwise, sludge should not be applied, as it will limit crop yields and, consequently, financial profitability.

\subsection{Regulatory Concerns}

Many countries or regions have specific regulations for the spreading of sludge and application as complementary fertilization, mostly for the use of sewage sludge but also for that of pulp and paper mill sludge. For example, the three main European framework directives relating to sewage sludge, waste, and nitrates regulate the use of sludge in the EU member states. The directives cover the prevention of possible harmful effects on soil, crops, animals, water, and human beings [50]. Regulations on the land application of sludge generally concern sludge characteristics in some regions reflecting directly on the quality of sludge and application manners of sludge. In addition, the application conditions are concerned, such as the site and soil characteristics, distance from surface water, and depth to groundwater $[9,50,51]$.

Although the purpose of the regulatory frameworks is to encourage to recycle nutrients and organic substances [50], the operators may be hesitant for the larger trials and utilizations as the legal framework and consequent, possible additional costs remain unclear. The regulatory framework for different type of operators may lead to different operations or cost levels. Hence, the impact of the operator classification, the sludge providers, plantation investors or farmers, or some other, increases the uncertainty on the final cost level.

Here the estimated expenses related sludge quality were excluded, as these costs are generated at the sludge treatment plant. The farmers or other plantation operators carry the risk related to the soil quality and production capacity, as well as suitability of the sludge-based complementary fertilization in the area. The analyses excluded this profitability element since this had required a proper soil analysis, which is not possible in the hypothetical case. The costs and processes related to contracts and permits are hypothetical cost elements. A real case may also include administrative expenses related to regulations or permits, for example, the declaration of sludge and the control of its application. This type of cost element was not assessed for this study.

\section{Conclusions}

Sludge can be recycled as a source of fibers or applied in agriculture and forestry as recycling nutrients within regulatory framework, although these technologies are not yet mature. Moreover, the production system or some other systems within close proximity can utilize sludge as an energy source by incinerating for energy conversion [11]. How- 
ever, the studied type of sludge is applicable as an additional, recycled fertilizer and soil improvement amendments in the wood production on plantations. This practice is considered highly valuable, as it involves the reduction of non-renewable nutrients which are becoming scarce and causing environmental problems concerning planetary boundaries.

The recycling of sludge promotes general resource efficiency by utilizing valuable particles of masses traditionally classified as waste. In addition, the use of recycled nutrients from pulp and paper integrated into the pulpwood production closes the economic loop that is illustrative of a circular bioeconomy. The model is applicable within other biomass processing industries, such as the bioenergy and food sectors. The business model promotes overall circular bioeconomy approaches.

The analyses resulted in slightly higher financial profitability compared with the original data from the reference study. The hypothetical circular bioeconomy model can be considered feasible regardless of the marginal impact on the financial profitability based on the conservative estimates of the applied parameters showed by the original analyses. The results showed that the financial profitability of biomass production is not sensitive to the plantation establishment and management costs. The profitability depends on the mean annal increment and product price.

The results could be even more promising if the nutrient and carbon recycling were studied simultaneously. It can be hypothesized further that the consideration of both nutrient and carbon recycling could increase direct financial profitability of tree growing compared to the tree growing based on mineral fertilization or the combination of mineral fertilizers and recycled nutrients and, even more, indirect value of ecosystem services, such as improved soil production capacity and water balance as well as mitigation of nutrient leaking to water ecosystems and climate change.

The economic profitability, i.e., the profitability of the national economy at large, beyond the operative financial analysis, of the establishment of a forest plantation on Imperata grasslands increases notably when the environmental impacts were considered in the analysis. Especially, the benefits of reforestation of over-logged indigenous forests are economically attractive. Moreover, the qualitative sustainability analysis here showed the holistic values among sustainability approaches and a variety of benefits at both the local and global levels. Consequently, further research is recommendable to assess the concrete impacts and benefits concerning the sustainability of the use of pulp and paper mill sludge to present higher values of this practice. In addition, further interdisciplinary studies on environmental aspects and economic and social approaches should be promoted to more profoundly evaluate the qualitative dimensions, the long-term environmental, economic, and social benefits, and to direct financial profitability.

Author Contributions: Research design and conceptualization M.M. and P.U.; methodology M.M. and P.U.; validation M.M., P.U., J.L., M.H. and L.L.; wuantitative model design, M.M.; quantitative analysis, P.U. and M.M.; qualitative analysis, J.L., P.U. and M.M.; investigation, P.U., M.M. and J.L.; resources, M.M., P.U. and J.L.; data curation, P.U., J.L., M.M. and M.H.; writing-original draft M.M., P.U. and J.L.; writing—review and editing, M.M.; visualization, P.U. All authors have read and agreed to the published version of the manuscript.

Funding: This work received no external funding.

Institutional Review Board Statement: Not applicable.

Informed Consent Statement: Not applicable.

Data Availability Statement: Not applicable.

Conflicts of Interest: The authors declare no conflict of interest. The material was gathered from open sources. The research is independent work without external funders. 


\section{Appendix A}

Table A1. Summary of all parameters used in the calculations of the different fertilization cost scenarios and their sources.

\begin{tabular}{llll}
\hline Parameter & Unit & Cost & Source \\
\hline Scenario 1: Basic data & USD/ha & 97.00 & {$[16]$} \\
Scenario 2: Sludge & USD/ha & 70.62 & Calculated. \\
Sludge application rate & $\mathrm{Mg} / \mathrm{ha}$ (wet) & 6.56 & Estimated based on [21,23] \\
Sludge transport cost & $\mathrm{USD} / \mathrm{t}$ & 5.00 & {$[35]$} \\
Sludge application cost & $\mathrm{USD} / \mathrm{ha}$ & 37.82 & {$[33]$} \\
Scenario 3: & $\mathrm{USD} / \mathrm{ha}$ & 87.68 & Calculated \\
Sludge + TSP & $\mathrm{Mg} / \mathrm{ha}($ wet) & 6.56 & Estimated based on [21,23] \\
Sludge application rate & $\mathrm{USD} / \mathrm{t}$ & 5.00 & {$[35]$} \\
Sludge transport cost & $\mathrm{USD} / \mathrm{ha}$ & 37.82 & [33] \\
Sludge application cost & $\mathrm{kg} / \mathrm{ha}$ & 30.00 & Estimated based on [23] \\
TSP application rate & $\mathrm{USD} /$ ton & 156.40 & Estimated based on [37] \\
TSP price & $\mathrm{USD} / \mathrm{acre}$ & 5.00 & Adjusted based on [39] \\
TSP spreading cost (original) & $\mathrm{USD} / \mathrm{ha}$ & 12.36 & Calculated \\
TSP spreading cost (used) &
\end{tabular}

Estimated conversion rate: 1 acre $=0.40468564$ hectare; $1 \mathrm{Mg}$ (wet) $=1$ ton.

\section{References}

1. Lampert, A. Over-exploitation of natural resources is followed by inevitable declines in economic growth and discount rate. Nat. Commun. 2019, 10, 1419. [CrossRef]

2. Kuokkanen, A.; Mikkilä, M.; Kahiluoto, H.; Kuisma, M.; Linnanen, L. The need for policy to address the food system lock-in: A case study of the Finnish context. J. Clean. Prod. 2017, 140, 933-944. [CrossRef]

3. Rockström, J.; Steffen, W.; Noone, K.; Persson, A.; Chapin, F.S.; Lambin, E.F.; Lenton, T.M.; Scheffer, M.; Folke, C.; Schellnhuber, H.J.; et al. A safe operating space for humanity. Nature 2009, 461, 472-475. [CrossRef]

4. Steffen, W.; Richardson, K.; Rockström, J.; Cornell, S.E.; Fetzer, I.; Bennett, E.M.; Biggs, R.; Carpenter, S.R.; de Vries, W.; Wit, C.A.; et al. Planetary boundaries: Guiding human development on a changing planet. Science 2015, 347, 6219. [CrossRef] [PubMed]

5. Foley, J.A.; Defries, R.; Asner, G.P.; Barford, C.; Bonan, G.; Carpenter, S.R.; Chapin, F.S.; Coe, M.T.; Daily, G.C.; Gibbs, H.K.; et al. Global consequences of land use. Science 2005, 309, 570. [CrossRef]

6. Worrell, E.; Phylipsen, D.; Einstein, D.; Martin, N. Energy Use and Energy Intensity of the U.S. Chemical Industry; Lawrence Berkeley National Lab: Berkeley, CA, USA, 2000.

7. Bennett, E.M.; Carpenter, S.R.; Caraco, N.F. Human impact on erodible phosphorus and eutrophication: A global perspective. Biosciences 2001, 51, 227-234. [CrossRef]

8. Haes, H.A.U.; Voortman, R.L.; Bastein, T.; Bussink, D.W.; Rougoor, C.W.; Weijden, W.J. Scarcity of Micronutrients in Soil, Feed, Food, and Mineral Reserves: Urgency and Policy Options; The Dutch Platform for Agriculture, Innovation and Society: Culemborg, The Netherlands, 2012.

9. Camberato, J.J.; Gagnon, B.; Angers, D.A.; Chantigny, M.H.; Pan, W.L. Pulp and paper mill by-products as soil amendments and plant nutrient sources. Can. J. Soil Sci. 2006, 86, 641-653. [CrossRef]

10. Benedetti, V. Bio-Solids have potential-An alternative method for the disposal of industrial waste as fertilizer in eucalyptus plantations. Pulp Pap. Int. 2014, 56, 38-41.

11. Bajpai, P. Management of Pulp and Paper Mill Waste; Springer International Publishing: New York, NY, USA, 2015. [CrossRef]

12. Joona, J.; Kuisma, M.; Alakukku, L.; Kahiluoto, H. Carbon flows of waste biomasses applicable to agricultural soils in Finland. In Global Assessment for Organic Resources and Waste Management, Proceedings of the 8th International Conference ORBIT2012, 12-14 June 2012, Rennes, France; Trémier, A., Dabert, P., Druilhe, C., Maudet, M.N., Barth, J., Siebert, S., Bidlingmaier, W., Eds.; Verlag ORBIT: Weimar, Germany, 2012; pp. 160-164.

13. CEPI. Discovering the High Potential of Pulp and Paper Production Residues; CEPI: Brussels, Belgium, 2004.

14. Zhang, L.; Xu, C.C.; Champagne, P. Energy recovery from secondary pulp/paper-mill sludge and sewage sludge with supercritical water treatment. Bioresour. Technol. 2010, 101, 2713-2721. [CrossRef]

15. Usman, K.; Khan, S.; Ghulam, S.; Khan, M.U.; Khan, N. Sewage Sludge: An important biological resource for sustainable agriculture and its environmental implications. Am. J. Plant Sci. 2012, 3, 1708-1721. [CrossRef]

16. Kosonen, M.; Otsamo, A.; Kuusipalo, J. Financial, economic and environmental profitability of reforestation of Imperata grassland in Indonesia. For. Ecol. Manag. 1997, 99, 249-259. [CrossRef]

17. Kosonen, M.; Otsamo, A.; Kuusipalo, J. Financial, Social and Environmental Profitability of Rehabilitation of Logged-Over Dipterocarp Forests-A Case Study from South-Kalimantan, Indonesia; Technical Report No. 63; Reforestation and Tropical Forest Management Project, Phase VI, ATA-267; The Ministry of Forestry of Indonesia/Ministry for Foreign Affairs of Finland/Enso Forest Development Oy Ltd.: Imatra, France, June 1996. 
18. Kuusipalo, J.; Ådjers, G.; Jafarsidik, Y.; Otsamo, A.; Tuomela, K.; Vuokko, R. Restoration of natural vegetation in degraded Imperata cylindrica grassland: Understorey development in forest plantations. J. Veg. Sci. 1996, 6, 205-210. [CrossRef]

19. Tuomela, K.; Otsamo, A.; Kuusipalo, J.; Vuokko, R.; Nikles, G. Effect of provenance variation and singling and pruning on early growth of Acacia mangium Willd. plantation on Imperata cylindrica (L.) Beauv. dominated grassland. For. Ecol. Manag. 1996, 84, 241-249. [CrossRef]

20. Utanun, P. Feasibility of the Use of Recycled Nutrients in Fast Growing Pulpwood Production. Ph.D. Thesis, Lappeenranta-Lahti University of Technology, Lappeenranta, Finland, 2015. Available online: https:/ lutpub.lut.fi/handle/10024/104633 (accessed on 22 June 2021).

21. Rashid, M.T.; Barry, D.; Goss, M. Paper mill biosolids application to agricultural lands: Benefits and environmental concerns with special reference to situation in Canada. Soil Environ. 2006, 25, 85-98.

22. Bresters, A.R.; Coulomb, I.; Deak, B.; Matter, B.; Saabye, A.; Spinosa, L.; Utvik, Å.Ø.; Uhre, L.; Meozzi, P. Sludge Treatment and Disposal: Management Approaches and Experiences; Environmental Issues, 7; European Environment Agency (EEA); International Solid Waste Association (ISWA): Copenhagen, Denmark, 1998.

23. Adjers, G.; Luukkanen, O. Fertilization Trial of Recently Plant Acacia Mangium Seedlings, 1988 ed.; Research Paper No. 3; Department of Silviculture, University of Helsinki: Helsinki, Finland, 1988; p. 77.

24. Florio, M. The rate of return of development projects: An international comparison. In Proceedings of the XII Riunione Scientifica: Politica Fiscale, Flessibilità dei Mercati e. Crescita, Pavia, Italy, 6-7 October 2000.

25. Liljeblom, E.; Vaihekoski, M. Investment evaluation methods and required rate of return in Finnish publicly listed companies. Liiketal. Aikakauskirja 2004, 1, 9-24.

26. World Bank. World DataBank: Explore, Create Report. Databases: World Development Indicators > Country: Indonesia > Series: Inflation, Consumer Prices (Annual \%) > Time: Year 1980-2020. Available online: https:/ / data.worldbank.org/indicator/FP.CPI. TOTL.ZG?locations=ID (accessed on 1 August 2021).

27. World Bank. World DataBank: Explore, Create Report. Databases: World Development Indicators > Country: United States > Series: Inflation, Consumer Prices (Annual \%) > Time: Year 1980-2020. Available online: https://data.worldbank.org/indicator/ FP.CPI.TOTL.ZG?locations=US (accessed on 1 August 2021).

28. Kuckartz, U. Qualitative Text Analysis: A Guide to Methods, Practice E Using Software; Metzler, K., Ed.; Sage: London, UK, 2014.

29. Fiksel, J.; Bruins, R.; Gatchett, A.; Gilliland, A.; Brink, M.T. The triple value model: A systems approach to sustainable solutions. Clean Technol. Environ. Policy 2013, 16, 691-702. [CrossRef]

30. Trautmann, N.M.; Porter, K.S.; Wagenet, R.J. Modern Agriculture: Its Effects on the Environment. Available online: http: //psep.cce.cornell.edu/facts-slides-self/facts/mod-ag-grw85.aspx (accessed on 1 August 2021).

31. Anderson, R.K.; Weddle, B.R.; Hillmer, T.; Geswein, A. Cost of Landspreading and Hauling Sludge from Municipal Wastewater Treatment Plants: Case Studies; Solid Waste Management Series, SW-619; United States Environmental Protection Agency: Columbus, OH, USA, 1977; Volume 530.

32. Ferrara, P.; Weber, B. Land Application of Sewage Sludge in the Willamette Valley: Farm Operator Attitudes and Municipal Costs; Special Report; Agriculture Experiment Station, Oregon State University: Corvallis, OR, USA, 1982; Volume 658.

33. Gray, C.W.; Chen, L.; Haro-Martí, M.E.; Chahine, M.; Neibling, H. Costs of Liquid-Manure Application Systems; University of Idaho, BUL 888; The College of Agricultural and Life Sciences, University of Idaho: Moscow, ID, USA, 2014.

34. Ministry of Environment. Towards a Recycling Society-The National Waste Plan for 2016. Available online: https://helda. helsinki.fi/handle/10138/38022 (accessed on 1 August 2021).

35. UNEP. P.T. PINDO DELI: Company Case Study; Green Industry Platform: Geneva, Switzerland, 2006.

36. US EPA. Handbook: Estimating Sludge Management Costs; National Service Center for Environmental Publications: Cincinnati, OH, USA, 1985.

37. Rasi, S.; Lehtonen, E.; Aro-Heinilä, E. From Waste to Traffic Fuel-Projects: Final Report, Finnish Case Regions; MTT Agrifood Research Finland: Jokioinen, Finland, 2012.

38. FAO. Fertilizer Use by Crop in Indonesia; FAO, Land and Water Development Division: Rome, Italy, 2005.

39. Ferguson, K.W.; McKinley, T.L. Fertilizer Cost Calculator. Available online: http:/ / economics.ag.utk.edu/fertilizer.html (accessed on 1 August 2021).

40. World Bank. World DataBank: Explore, Create Report. Databases: Global Economic Monitor (GEM) Commodities > Series: Woodpulp, \$/mt, Real 2010\$ > Time: Annual, Year 1995-2013 Country: World. Available online: https:/ databank.worldbank. org/source/global-economic-monitor-(gem) (accessed on 1 August 2021).

41. Kahiluoto, H.; Smith, P.; Moran, D.; Olesen, J.E. Enabling food security by verifying agricultural carbon. Nat. Clim. Change 2014, 4, 309-311. [CrossRef]

42. Otsamo, A.; Adjers, G.; Hadi, T.S.; Kuusipalo, J.; Tuomela, K.; Vuokko, R. Effect of site preparation and initial fertilization on the establishment and growth of four plantation tree species used in reforestation of Imperata cylindrica (L.) Beauv. dominated grasslands. For. Ecol. Manag. 1995, 73, 271-277. [CrossRef]

43. Culp, J.; Podemski, C.; Cash, K. Interactive effects of nutrients and contaminates from pulp mill effluents on riverine benthos. J. Aquat. Ecosyst. Stress Recovery 2000, 8, 67-75. [CrossRef]

44. Millennium Ecosystem Assessment. Ecosystems and Human Well-Being: Synthesis; Island Press: Washington, DC, USA, 2005.

45. Alexander, M. Introduction to Soil Microbiology, 2nd ed.; John Wiley \& Sons: New York, NY, USA, 1977. 
46. Simard, R.R.; Baziramakenga, R.; Yelle, S.; Coulombe, J. Effects of de-inking paper sludges on soil properties and crop yields. Can. J. Soil Sci. 1998, 78, 689-697. [CrossRef]

47. Zibilske, L.M. Dynamics of nitrogen and carbon in soil during papermill sludge decomposition. Soil Sci. 1987, 143, 26-33. [CrossRef]

48. Dolar, S.G.; Boyle, J.R.; Keeney, D.R. Paper mill sludge disposal on soils: Effects on the yield and mineral nutrition of oats (Avena sativa L.). J. Environ. Qual. 1972, 1, 405-409. [CrossRef]

49. McClellan, T. Nitrogen, Immobization. Available online: http://www.ctahr.hawaii.edu/mauisoil/c_nutrients01.aspx (accessed on 1 August 2021).

50. EFAR. Regulation in Europe. Available online: http:/ / www.efar.be/biosolid-production/\#REGULATION-IN-EUROPE (accessed on 1 August 2021).

51. CPI. Code of Good Practice for Landspreading Paper Mill Sludges; CPI: Swindon, UK, 2014. 